\title{
Enhancement of Dissolution of Fenofibrate Using Complexation with Hydroxy Propyl $\beta$-Cyclodextrin
}

\section{Hidroksi Propil $\beta$-Siklodekstrin ile Kompleksasyon Kullanılarak Fenofibratın Çözünmesinin Arttırılması}

\author{
(D) Sachin K. JAGDALE1 ${ }^{*}$, (D) Mohammad H. DEHGHAN2, (D) Nilesh S. PAUL ${ }^{3}$ \\ 1Marathwada Mitra Mandal's College of Pharmacy, Pune, India \\ 2Y. B. Chavan College of Pharmacy, Aurangabad, India \\ 3MGM Institute of Bioscienceand Technology, Aurangabad, India
}

\section{ABSTRACT}

Objectives: The aim of the present study was to enhance the dissolution rate of fenofibrate using complexation with hydroxy propyl $\beta$-cyclodextrin (HPßCD).

Materials and Methods: The phase solubility behavior of fenofibrate was studied in various concentrations of (HP $\beta C D)$ aq. solution at $37^{\circ} \mathrm{C}$. The solubility of fenofibrate increased with an increase in the amount of HPßCD aq. solution. Gibbs free energy $\left(\triangle G^{\circ}\right)_{t r}$ values were all negative. Complexes of fenofibrate with HP $\beta C D$ were prepared in 1:1 ratio by kneading and coprecipitation. These complexes were evaluated by dissolution studies, fourier transform infrared (FTIR) spectroscopy, and differential scanning calorimetry (DSC) studies.

Results: The complexation of fenofibrate with HP $\beta C D$ exhibited an enhanced dissolution rate. The mean dissolution time of fenofibrate decreased significantly upon complexation. FTIR studies showed the formation of intermolecular hydrogen bonding between fenofibrate and HP $\beta C D$. DSC studies indicated a loss in crystalline state of fenofibrate in complexes.

Conclusion: Complexation with HP $\beta C D$ can be used as a useful tool for the enhancement of dissolution of fenofibrate.

Key words: Fenofibrate, hydroxy propyl $\beta$-cyclodextrin, solubility, Gibbs free energy, dissolution rate

öz

Amaç: Bu çalışmanın amacı, hidroksi propil $\beta$-siklodekstrin (HPßCD) ile kompleksasyon kullanarak fenofibratın çözünme hızını arttırmaktı.

Gereç ve Yöntemler: Fenofibratın faz çözünürlük davranışları (HP $\beta C D$ ) çeşitli konsantrasyonlardaki sulu çözeltisinde, $37^{\circ} \mathrm{C}^{\prime}$ de çalışıldı. Fenofibratın çözünürlüğü, artan miktarda HPßCD'nin sulu çözeltisi ile arttı. Gibbs serbest enerji $\left(\Delta G^{\circ}\right)_{t r}$ değerlerinin hepsi negatifti. HPßCD ile fenofibrat kompleksleri, 1:1 oranında yoğurma ve kopresipitasyon ile hazırlandı. Bu kompleksler, çözünme çalışmaları, fourier dönüşümü kızılötesi spektroskopisi (FTIR) ve diferansiyel tarama kalorimetrisi (DSC) çalışmaları ile değerlendirildi.

Bulgular: Fenofibratın HPßCD ile kompleksasyonu, gelişmiş bir çözünme hızı sergiledi. Fenofibratın ortalama çözünme süresi, kompleksasyon üzerine önemli ölçüde azaldı. FTIR çalışmaları fenofibrat ve HPßCD arasında moleküller arası hidrojen bağlanmasının oluşumunu göstermiştir. DSC çalışmaları komplekslerde kristalin fenofibrat durumunda bir kayıp olduğunu gösterdi.

Sonuç: HPßCD ile kompleksasyon, fenofibratın çözünmesinin arttırılması için yararlı bir araç olarak kullanılabilir. Anahtar kelimeler: Fenofibrat, hidroksi propil $\beta$-siklodekstrin, çözünürlük, Gibbs serbest enerjisi, çözünme hızı

*Correspondence: E-mail: sachin10pharmacy@gmail.com, Phone: +91-7588938173 ORCID-ID: orcid.org/0000-0001-5714-5508 Received: 09.11.2017, Accepted: 14.12.2017

๑Turk J Pharm Sci, Published by Galenos Publishing House. 


\section{INTRODUCTION}

Fenofibrate, propan-2-yl 2-[4-(4-chlorobenzoyl) phenoxy]2-methylpropanoate, is a fibric acid derivative useful as an antilipidemic agent. Fenofibrate is a hypolipidemic drug that reduces the levels of lipids (fats) in the blood. It is a white crystalline powder, practically insoluble in water (log $\mathrm{p}=5.24$ ). Its low water solubility and poor dissolution rate cause problems in formulation development and restrict its therapeutic application by influencing the rate of absorption and the onset of action.

Consequently, its bioavailability is incomplete, irregular, and often varies from one person to another. As a result, commercially available doses are of higher strength and require repeated dosing. From an economic point of view, this low bioavailability of drug leads to wastage of more amounts of drug after oral administration, increasing the cost of medication. Therefore, it is very important to find appropriate formulation approaches to enhance the aqueous solubility, dissolution rate, and thus the bioavailability of poorly soluble drugs. Nowadays, many approaches are used to enhance the solubility and dissolution rate of poorly soluble drugs by the use of pharmaceutical technology. ${ }^{2}$ Physical modification often aims to increase the surface area, solubility, and/or wettability of the powder. Other approaches include cosolvency using various solvent blends, cyclodextrin complexation, ${ }^{3}$ use of surfactants, ${ }^{4}$ salt forms, ${ }^{5}$ prodrugs, ${ }^{6}$ and alteration of crystal properties. ${ }^{7,8}$

A number of different microorganisms and plants produce certain enzymes called cyclodextrin glucosyltransferases, which degrade starch to cyclic products called cyclodextrins. These cyclodextrins are cyclic oligosaccharides involving $(\alpha-1,4)$-associated $\alpha$-D-glucopyranose units and contain a genuinely lipophilic cavity and a hydrophilic external surface. They are shaped like truncated cones rather than perfect cylinders. In light of such qualities, cyclodextrins are able to form inclusion complexes both in solid state and in solution state, in which every guest entity is surrounded by the hydrophobic environment of the cyclodextrin cavity. Upon inclusion, the water solubility of the guest can increase as well as its bioavailability. ${ }^{910}$ This inclusion complex formation leads to alteration of the physicochemical and biological properties of the guest molecules and may eventually have considerable pharmaceutical potential.1112

The naturally occurring $\alpha^{-}, \beta-$, and $\gamma$-cyclodextrin consist of six, seven, and eight glucopyranose units, respectively. Natural cyclodextrins like $\beta$-cyclodextrin have limited aqueous solubility and the complexes formed from the interaction of lipophilic/hydrophobic drugs with these cyclodextrins may be of limited solubility. This may result in precipitation of solid cyclodextrin complexes from water and other aqueous systems. Cyclodextrin derivatives of pharmaceutical interest include the derivatives of these naturally occurring $\beta$ - and $\gamma$-cyclodextrins. Out of these cyclodextrin derivatives, hydroxy propyl $\beta$-cyclodextrin (HP $\beta C D$ ) appears the most useful as a pharmaceutical complexing agent because of its complexing ability, low cost, and other properties. The approach of cyclodextrin complexation can be used to increase the water solubility and dissolution rate of poorly soluble drugs and to solve bioavailability problems.

As fenofibrate dissolves very slightly in water, the present study was undertaken to overcome the limitations existing in available fenofibrate products so as to improve the dissolution profile, absorption characteristics, and bioavailability and to reduce the dose required for administration to attain a desired effect.

The study also aimed to develop a method for preparation of an inclusion complex of fenofibrate with $\mathrm{HP} \beta C D$ that is efficient and economical, simple, and less time consuming than other methods.

Thus, the present study was performed to enhance the solubility and dissolution rate of fenofibrate using complexation with $H P \beta C D$ in order to attain a therapeutic effect. The possible interactions between fenofibrate and HP $\beta C D$ in both solid state and liquid states were investigated. The solid state interaction was investigated by fourier transform infrared (FTIR) spectroscopy and differential scanning calorimetry (DSC) studies. The interaction in solution was studied by phase solubility analysis and dissolution experiments.

\section{MATERIALS AND METHODS}

\section{Materials}

A gift sample of fenofibrate was received from Shreya Life Sciences, (Aurangabad, India). HP $\beta C D$ was obtained from Wockhardt Pharmaceuticals (Aurangabad, India). All other solvents and ingredients used were of analytical grade.13,14

\section{Methods}

\section{Phase solubility studies}

Phase solubility studies were performed in triplicate according to the method reported by Higuchi and Connors. ${ }^{15}$ An excess of drug was added to $5-\mathrm{mL}$ portions of distilled water in vials each containing a variable amount of HPBCD ( $2 \mathrm{mM}$ to $10 \mathrm{mM}$ ). All the above solutions were subjected to sonication for $30 \mathrm{~min}$ and then allowed to stand at room temperature $\left(\sim 25^{\circ} \mathrm{C}\right)$ for 48 $\mathrm{h}$ without disturbance to attain saturation equilibrium. These saturated systems were carefully filtered through Whatman filter paper (no. 41) and were analyzed spectrophotometrically at $287 \mathrm{~nm}$ after appropriate dilutions on a ultraviolet (UV)visible spectrophotometer.

The solubility of fenofibrate in every HPßCD solution was calculated and a phase solubility diagram was drawn between solubility of fenofibrate and different concentrations of HP $\beta C D$. The apparent stability constant $(\mathrm{Kc})$ was calculated by using the formula ${ }^{15}$,

Stability constant $(K c)=\frac{\text { Slope }}{\text { So }(1-\text { slope })^{\prime}}$.........................................

where $\mathrm{So}=$ aqueous solubility of fenofibrate.

The Gibbs free energy of transfer $\left(\Delta G^{\circ}\right)_{t r}$ of fenofibrate from pure water to the aqueous solution of carrier was calculated $a^{14}$;

$\Delta \mathrm{Gtr}=2.303 \mathrm{RT}$ LogSo/ Ss, ........................................ 
where So/Ss is the ratio of molar solubility of fenofibrate in aqueous solution of $H P \beta C D$ to that of the same medium without $\mathrm{HP} \beta \mathrm{CD}$.

\section{Preparation of solid binary systems}

Preparation of physical mixture of fenofibrate with $H P \beta C D$

The physical mixture of fenofibrate with HP $\beta C D$ containing molar weight ratio 1:1 (fenofibrate:HP $\beta C D$ ) was prepared, followed by passing through a sieve (no. 72) with minimum abrasion.

\section{Preparation of inclusion complex by kneading method ${ }^{15}$}

Stoichiometric quantities $(1: 1)$ of fenofibrate:HP $\beta C D$ were accurately weighed. HP $\beta C D$ was added to the mortar, and a small amount of ethanol:water $(1: 1 \mathrm{v} / \mathrm{v})$ was added while triturating to get a slurry-like consistency. Then slowly the drug was incorporated into the slurry, and trituration was continued for a further $45 \mathrm{~min}$. The slurry was then dried at $50^{\circ} \mathrm{C}$ for $24 \mathrm{~h}$, pulverized, passed through a no. 72 sieve, and stored in desiccators until further use.

\section{Preparation of inclusion complex by coprecipitation}

Fenofibrate and HP $\beta C D$ in 1:1 molar ratio were accurately weighed. Saturated cyclodextrin solution was prepared with HP $\beta C D$ and water. Then fenofibrate solution in methanol was added slowly and a suspension was formed. The suspension was stirred at $40^{\circ} \mathrm{C}$ for $30 \mathrm{~min}$ and the stirring was continued at room temperature $\left(25^{\circ} \mathrm{C}\right)$ for $30 \mathrm{~min}$. The obtained masses were filtered through Whatman filter paper no. 41 and dried at $50^{\circ} \mathrm{C}$ in an oven for $24 \mathrm{~h}$. The dried complexes were pulverized and passed through a no. 72 sieve and stored in desiccators until further use. ${ }^{16}$

The yield for HP $\beta C D$ complex was not significant. Therefore, we used the following method for coprecipitation.

Fenofibrate and HPBCD in 1:1 molar ratio were accurately weighed. Cyclodextrin solution was prepared with HPBCD and water. Then fenofibrate solution in methanol was added slowly to the above solution and a suspension was formed. The suspension was stirred at $40^{\circ} \mathrm{C}$ for $30 \mathrm{~min}$ and kept stirring at room temperature for $12 \mathrm{~h}$. The obtained masses were refrigerated for $24 \mathrm{~h}$. Then these masses were filtered through Whatman filter paper no. 41 and dried at $50^{\circ} \mathrm{C}$ in an oven for 24 h. The dried complexes were pulverized and passed through a no. 72 sieve and stored in desiccators until further use. ${ }^{17}$

\section{Dissolution studies}

As fenofibrate is a lipophilic compound and practically insoluble in water, dissolution study of fenofibrate dosage forms necessitates modifications in the dissolution medium. Sodium lauryl sulfate (SLS) of concentration $20 \mathrm{mM}$ and above provides sink conditions. ${ }^{18,19}$

Dissolution studies of fenofibrate, physical mixture, kneaded product, and coprecipitated product were performed using the U.S. Pharmacopeia (USP) model digital tablet dissolution test apparatus II (Electrolab, Mumbai) at paddle rotation speed of 75 $\mathrm{rpm}$ in $900 \mathrm{~mL}$ of $20 \mathrm{mM} \mathrm{SLS}$ at $37.0 \pm 0.5^{\circ} \mathrm{C}$.
The physical mixture equivalent to $145 \mathrm{mg}$ of fenofibrate was weighed using a digital balance (Make Eagle, India) and added to dissolution medium. Then $5-\mathrm{mL}$ samples were withdrawn at predetermined intervals and replaced with fresh dissolution medium and suitably diluted. Diluted samples were then assayed for fenofibrate content by measuring the absorbance at $287 \mathrm{~nm}$ using a UV-visible spectrophotometer (Jasco model V630, Japan). The dissolution studies were either performed until all the solids were completely dissolved or stopped at $2 \mathrm{~h}$ if the duration of dissolution was longer. Studies were performed in triplicate $(n=3)$. Mean values of cumulative drug release were calculated for plotting the release curve.

\section{Fourier transform infrared spectroscopy}

FTIR spectra were obtained using an FT/IR-4100 spectrophotometer (Jasco, Japan). The samples (fenofibrate, physical mixture, and drug:cyclodextrin complexes) were previously ground and mixed thoroughly with potassium bromide, an infrared transparent matrix, at 1:5 (sample: $\mathrm{KBr}$ ) ratio, respectively. Forty scans were obtained from 4000 to $400 \mathrm{~cm}^{-1}$.

\section{Differential scanning calorimetry studies}

The DSC ther mograms were obtained on a DSC (Shimadzu DSC60 thermal analyzer, Japan). The instrument was calibrated using indium as standard. Samples $(5 \mathrm{mg}$ ) were heated in sealed aluminum pans under nitrogen using the following program: hold for $10 \mathrm{~min}$ at $40^{\circ} \mathrm{C}$ and heat from 40.0 to $250.0^{\circ} \mathrm{C}$ at a scanning rate of $10^{\circ} \mathrm{C} / \mathrm{min}$. Then the samples were subjected to DSC studies. Samples were sealed in $40-\mu \mathrm{L}$ aluminum pans. An identical empty pan was used as a reference. The samples were scanned at $10^{\circ} \mathrm{C} / \mathrm{min}$ with a $50 \mathrm{~mL} / \mathrm{min}$ nitrogen purge.

\section{RESULTS AND DISCUSSION}

\section{Phase solubility studies}

The phase solubility profiles of fenofibrate-HP $\beta C D$ are presented in Figure 1. This plot showed that aqueous solubility of the drug increases linearly as a function of HP $\beta C D$. The phase solubility profile of fenofibrate with HP $\beta C D$ can be classified as $A_{L}$-type. The linear host-guest correlation coefficient $r=0.9969$ $\left(r^{2}=0.994\right)$ with a slope $(m)$ of 0.004 suggested the formation

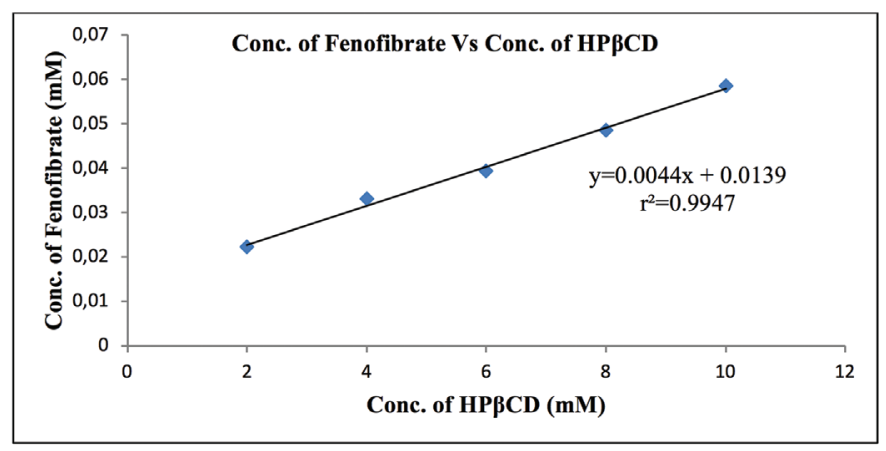

Figure 1. Phase solubility diagram of the fenofibrate-HP $\beta C D$ system in water

HP $\beta C D$ : Hydroxy propyl $\beta$-cyclodextrin 
of a 1:1 complex with respect to HP $\beta C D$ concentrations. The apparent stability constants, $K_{1: 1}$, obtained from the slope of the linear phase solubility diagram was $630.0006 \mathrm{M}^{-1}$ for HPßCD [Eq. (1)]. The $K_{1: 1}$ value suggested that fenofibrate formed more stable complex with HP $\beta C D$.

An indication of the process of transfer of fenofibrate from pure water to the aqueous solution of HP $\beta C D$ may be obtained from the values of the Gibbs free energy change (Table 1). The values of Gibbs free energy associated with the aqueous solubility of fenofibrate in the presence of HPßCD ( were all negative for $\mathrm{HP} \beta C D$ at various concentrations, indicating the spontaneous nature of the drug solubilization. The values decreased with increasing HPBCD concentration, demonstrating that solubilization was more favorable as concentration of HP $\beta C D$ increased.

Table 1. Effect of HP $\beta C D$ concentration and Gibbs free energy on solubility of fenofibrate

\begin{tabular}{llll} 
Sr. no. & $\begin{array}{l}\text { Concentration of } \\
\text { HP } \beta C D(m M)\end{array}$ & $\begin{array}{l}\text { Concentration of } \\
\text { fenofibrate }(\mathrm{mM})\end{array}$ & $\begin{array}{l}(\Delta \mathrm{Gtr}) \\
(\mathrm{J} / \mathrm{Mol})\end{array}$ \\
\hline 1 & 0 & 0.007012 & 0 \\
\hline 2 & 2 & 0.022256 & -684.006 \\
\hline 3 & 4 & 0.033079 & -918.699 \\
\hline 4 & 6 & 0.039483 & -1023.508 \\
\hline 5 & 8 & 0.048561 & -1146.070 \\
\hline 6 & 10 & 0.058632 & -1257.683 \\
\hline
\end{tabular}

HP $\beta C D$ : Hydroxy propyl $\beta$-cyclodextrin

\section{Dissolution studies}

The results of the dissolution studies for individual samples (fenofibrate alone, PMs, and complexes) over $2 \mathrm{~h}$ are shown in Figure 2. Onset of dissolution of pure fenofibrate is very slow, with about $13.29 \%$ of drug being dissolved in $120 \mathrm{~min}$. Complexes of fenofibrate with HP $\beta C D$ had considerably enhanced dissolution rates as compared to pure drug fenofibrate and PMs.

Percentage dissolution efficiencies (\%DE) values were computed for comparative analysis of all the formulations. The $\% D E$ values in the initial time period of the dissolution study, i.e.,

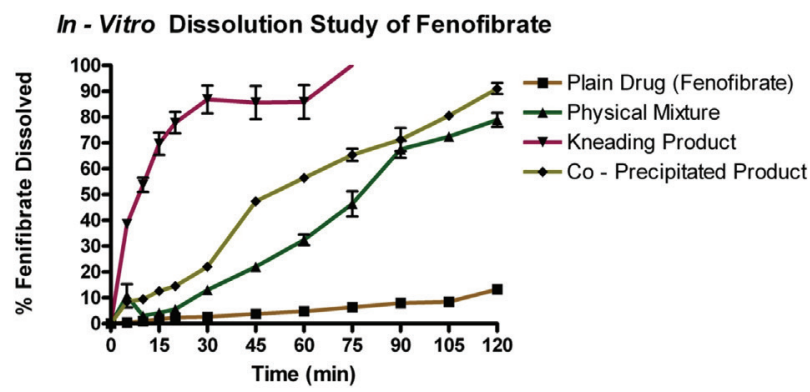

Figure 2. In vitro dissolution study of fenofibrate-HPßCD complexes HP $\beta C D$ : Hydroxy propyl $\beta$-cyclodextrin
$\% \mathrm{DE}_{10 \mathrm{~min}}$, provide comparative information for very fast releasing formulations, whereas those for $\% \mathrm{DE}_{60 \mathrm{~min}}$ provide relative information about both fast and slow releasing formulations. The values of $\% \mathrm{DE}_{60 \mathrm{~min}}$ for the pure drug increased to $32.45 \%$ in PMs and up to $87.39 \%$ in kneaded product and $56.46 \%$ in coprecipitated products. The change in $\mathrm{DE}_{60 \mathrm{~min}}$ of the drug in its PMs and complexes is statistically significant ( $p<0.05)$.

The results of \% dissolution and dissolution efficiency study indicate an improvement in the dissolution rate of fenofibrate in cyclodextrin complexes by both techniques. The improvement in dissolution rate is possibly caused by several factors:

a) the strong hydrophilic character of HP $\beta C D$, which improves the water penetration and wettability of the hydrophobic fenofibrate,

b) the optimal dispersion of fenofibrate to HP $\beta C D$,

c) the absence of crystals corresponds to lower energy required for dissolution, and

d) the intermolecular hydrogen bonds and the molecular dispersion of fenofibrate on HP $\beta$ CD lead to partial miscibility, improving the hydrophilic characteristics of the drug substance via interactions with $\beta C D$ the improvement of dissolution rate of fenofibrate in the physical mixture is due to increased wettability of the drug powder. ${ }^{20}$

Kneading showed better dissolution than coprecipitation. This could be attributed to the improved wetting provided by cyclodextrins in kneading than in coprecipitation, as earlier reported by Mukne for triamterene ${ }^{21}$ and Deshmukh for ziprasidone. $^{22}$ Thus it can be concluded that kneading is better for complexation than coprecipitation.

\section{FTIR spectroscopy}

The FTIR spectra of the systems of fenofibrate-HP $\beta C D$ and those of pure components are shown in Figure 3. When the systems are compared, it can be observed that the ester group stretching band at $1727.91 \mathrm{~cm}^{-1}$ broadens and shifts towards higher wavenumbers, indicating change in the intermolecular $\mathrm{H}$-bonds of the drug upon complexation. Similar modifications

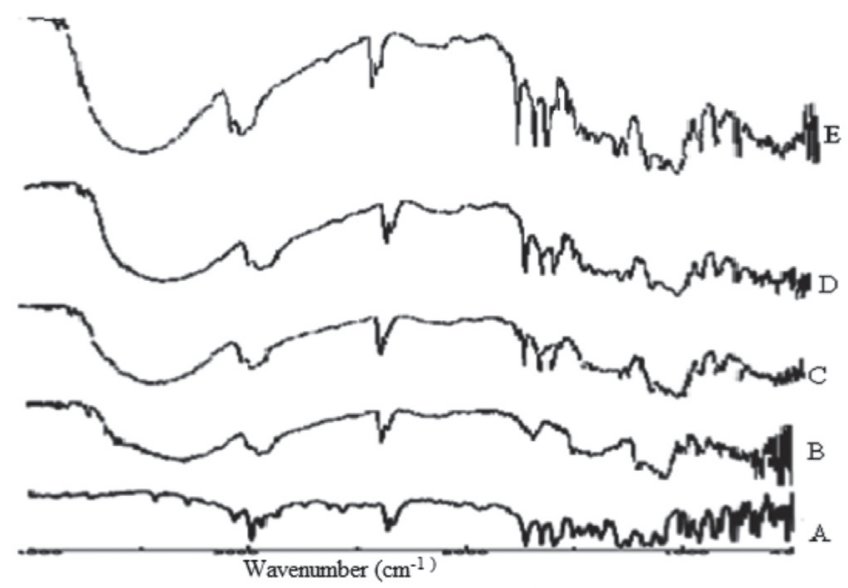

Figure 3. FTIR spectrograms of a) pure drug fenofibrate, b) HP $\beta C D, c)$ physical mixture, d) kneading product, e) coprecipitated product FTIR: Fourier transform infrared, HPßCD: Hydroxy propyl $\beta$-cyclodextrin 


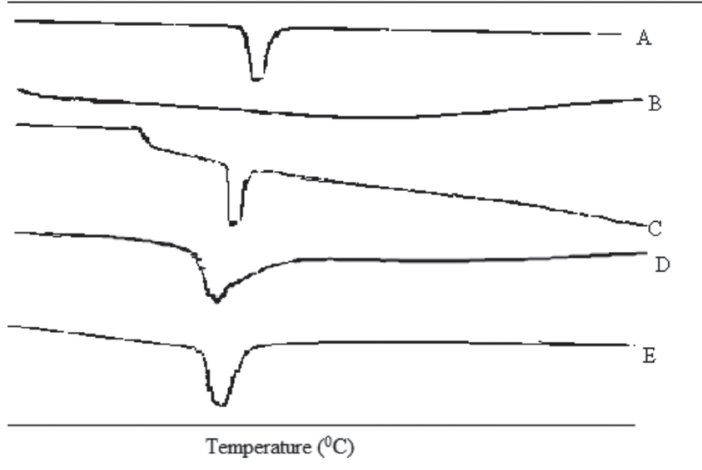

Figure 4. DSC curves of a) fenofibrate, b) HP $\beta C D, c)$ physical mixture, d) kneading product, e) coprecipitation product

DSC: Differential scanning calorimetry, HP $\beta C D$ : Hydroxy propyl $\beta$-cyclodextrin

were seen in the combination signal of the ester group, which indicates change in the interaction of this group when the complex is formed. In addition, the bands at $1050-1340 \mathrm{~cm}^{-1}$ corresponding to antisymmetric vibrations of the aryl ether group and $\mathrm{C}-\mathrm{O}$ stretching of esters broaden in some cases and in others peaks vanish upon complexation. The decreased intensity and vanishing of the band are associated with the outof-plane bending of the aromatic $\mathrm{C}-\mathrm{H}$ bonds at $824-844 \mathrm{~cm}^{-1}$, evidence of the inclusion of the benzene ring. ${ }^{23}$

Finally, the $\mathrm{C}-\mathrm{H}$ stretching seen at $3032-3052 \mathrm{~cm}^{-1}$ vanishes in the complexes, indicating that complexation has occurred.

\section{DSC studies}

The DSC thermogram of HP $\beta C D$ showed a straight line. The DSC curve of fenofibrate showed a broad endothermic peak in the range of $80-90^{\circ} \mathrm{C}$ owing to the melting point of the drug. The peak of fenofibrate showed changes in terms of peak area and $\Delta \mathrm{H}$ (heat of fusion) value (Table 2 ) in the case of the complexes as compared to the physical mixture comprising drug:HP $\beta C D$ in the same ratio. This suggested that the presence of HP $\beta C D$ resulted in complexation of fenofibrate. The change in peak height and broadening of peaks may be attributed to loss of crystallinity. ${ }^{24}$

\begin{tabular}{lll}
$\begin{array}{l}\text { Table 2. Peak area and heat of fusion }(\Delta \mathrm{H}) \text { values obtained from } \\
\text { DSC curves }\end{array}$ & Height $\mathrm{mW}$ & $\Delta \mathrm{H}(\mathrm{J} / \mathrm{gm})$ \\
\hline Sample & -8.82 & 93.83 \\
\hline Fenofibrate & -5.35 & 20.21 \\
\hline Physical mixture (P1) & -2.44 & 12.03 \\
\hline Kneading product (B1) & -3.41 & 12.7 \\
\hline Coprecipitation product (C1) &
\end{tabular}

DSC: Differential scanning calorimetry

\section{CONCLUSIONS}

The solubility and dissolution rate of fenofibrate can be enhanced by the use of complexes of fenofibrate with HPBCD. The solubilization effects of $H P \beta C D$, reduction of particle aggregation of the drug, loss in crystallinity, increased wettability and dispersibility, and alteration in the surface properties of the drug particles might be responsible for the enhanced solubility and dissolution rate of fenofibrate from its complexes and physical mixtures.

Kneading showed better dissolution than coprecipitation. This could be attributed to the improved wetting provided by cyclodextrins in kneading than in coprecipitation.

It is concluded that fenofibrate- HP $\beta C D$ complexation results in an increase in the solubility and dissolution rate of the drug, suggesting a possible enhancement of its oral bioavailability.

\section{ACKNOWLEDGEMENTS}

The authors are grateful to Shreya Life Sciences Ltd and Wockhardt for providing gift samples of fenofibrate and cyclodextrin, respectively. The authors are thankful to $Y B$ Chavan College of Pharmacy, Aurangabad, and Marathwada Mitra Mandal's College of Pharmacy, Kalewadi, Pune.

Conflict of Interest: No conflict of interest was declared by the authors.

\section{REFERENCES}

1. Gidwani SK, Singurkar PS. Fenofibrate- Cyclodextrin Inclusion Complexes and Other Pharmaceutical Composition. US patent US 2003/0220293A1. 2003 Nov 27.

2. Yalkowsky SH. Solubility and Solubilization in Aqueous Media. Oxford University Press; Cambridge; 1999.

3. Loftsson T, Brewster ME. Pharmaceutical application of cyclodextrins. 1.Drug solubilization and stabilization. J Pharm Scis. 1996;85:1017-1025.

4. Rangel-Yagui CO, Pessoa A Jr, Tavares LC. Micellar Solubilization of drugs. J Pharm Pharm Sci. 2005;8:147-163.

5. Serajuddin ATM, Pudipeddi M. Salt selection strategies. In: Stahl PH, Wermuth CG. eds. Handbook of Pharmaceutical Salts Properties Selection and Use. Verlag Helvetica Chemica Acta/Wiley-VCH, Switzerland; Federal Republic of Germany; 2002:158-159.

6. Stella VJ, Nti-Addae KW. Prodrug strategies to overcome poor water solubility. Adv Drug Deliv Rev. 2007;59:677-694.

7. Blagden N, de Matas M, Gavan PT, York P. Crystal engineering of active pharmaceutical ingredients to improve solubility and dissolution rates. Adv Drug Deliv Rev. 2007;59:617-630.

8. Shefter E, Higuchi T. Dissolution behavior of crystalline solvated and nonsolvated forms of some pharmaceuticals. J Pharm Sci. 1963;52:781791.

9. Hickey MB, Peterson ML, Scoppettuolo LA, Morrisette SL, Vetter A, Guzmán H, Remenar JF, Zhang Z, Tawa MD, Haley S, Zaworotko MJ, Almarsson O. Performance comparison of a co-crystal of carbamazepine with marketed product. Eur J Pharm Biopharm. 2007;67:112-119.

10. Szejtli, J. Cyclodextrins in drug formulations: Part I. Pharmaceutical Technology. 1991;3:15-22.

11. Uekama K, Hirayama F, Irie T. Cyclodextrin drug carrier systems. Chem Rev. 1998;98:2045-2076.

12. Loftsson T, Masson M. Cyclodextrin in topical drug formulations: theory and practice. Int J Pharm. 2001;225:15-30. 
13. Rawat S, Jain SK. Solubility enhancement of celecoxib using betaCyclodextrin inclusion complexes. Eur J Pharm Biopharm. 2004;57:263267.

14. Hamada H, Ishihara K, Masuoka N, Mikuni K, Nakajima N. Enhancement of Water-Solubility and Bioactivity Paclitaxel Using Modified Cyclodextrins. J Biosci Bioeng. 2006;102:369-371.

15. Higuchi T, Connors K. Phase solubility techniques. Advances in Analytical Chemistry and Instrumentation. 1965;7:117-212.

16. Asker AF, Whitworth CW. Dissolution of acetylsalicylic acid from acetylsalicylic acid-polyethylene glycol 6000 coprecipitates. Pharmazie 1975;30:530-531.

17. Veiga $F$, Dias $T$, Kedzierewicz $F$, Sousa $A$, Maincent $P$. Inclusion complexation of tolbutamide with $\beta$-cyclodextrin and hydroxypropyl- $\beta$ cyclodextrin. Int J Pharm. 1996;129:63-71.

18. Liu L, Zhu S. Preparation and characterization of inclusion complexes of prazosin hydrochloride with $\beta$-cyclodextrin and hydroxypropyl-betacyclodextrin. J Pharm and Biomed Anal. 2006;40:122-127.

19. Stancanelli R, Crupi V, De Luca L, Ficarra P, Ficarra R, Gitto R, Guardo M, Iraci N, Majolino D, Tommasini S, Venuti V. Improvement of water solubility of non- competitive AMPA receptor antagonist by complexation with beta-cyclodextrin. Bioorg Med Chem. 2008;16:8706-8712.

20. Crison JR, Shah VP, Skelly JP, Amidon GL. Drug dissolution into micellar solutions: development of a convective diffusion model and comparison to the film equilibrium model with application to surfactant-facilitated dissolution of carbamazepine. J Pharm Sci. 1996;85:1005-1011.

21. Jamzad S, Fassihi R. Role of Surfactant and pH on Dissolution Properties of Fenofibrate and Glipizide A Technical Note. AAPS PharmSciTech. 2006;7:33.

22. Van den MG, Augustijns $P$, Blaton N, Kinget R. Physico chemical characterization of solid dispersions of temazepam with polyethylene glycol 6000 and PVP K30. Int J Pharm. 1998;164:67-80.

23. Mukne AP, Nagarsenkar MS. Triamterene-beta- cyclodextrin systems: Preparation, Characterization and in vivo evaluation. AAPS Pharmasci Tech. 2004;5:19

24. Deshmukh SS, Potnis VV, Shelar DB, Mahaparale PR. Studies on inclusion complexes of ziprasidone hydrochloride with $\beta$ cyclodextrin and hydroxyl propyl $\beta$ cyclodextrin. Indian Drugs, 2007;44:677-682. 